\title{
The ECHR and Private Intercountry Adoptions in Germany and the Netherlands: Lessons Learned from Campanelli and Paradiso v. Italy
}

\author{
E.C. Loibl*
}

\section{Introduction}

Within the past couple of years, numerous reports about abusive practices within the intercountry adoption system emerged. Children were purchased from their impoverished families, or abducted from their homes, the streets, or orphanages. ${ }^{1}$ Vulnerable birth parents were coerced or deceived in order to obtain their consent for an adoption. ${ }^{2}$ Birth certificates and other documents that are necessary for an adoption were falsified or fabricated to hide the children's origin. ${ }^{3}$ Government officials or judges in the sending countries were being bribed to approve a fraudulent intercountry adoption. ${ }^{4}$ The intercountry adoption system has an intrinsically criminogenic character: the great imbalance between the demand for and the supply of adoptable babies, combined with the large sums of Western money, incite greedy actors in poor countries to illegally obtain children for adoption and tempt even humanitarian organizations into abusive conduct. ${ }^{5}$ This renders intercountry adoption conducive to abuses.

Private intercountry adoptions, meaning adoptions that adopters pursue without the involvement of an accredited adoption agency and the authorities in the receiving country, are particularly prone to abuses. ${ }^{6}$ This is why the 1993 Hague Convention on Protection of Children and Co-operation in Respect of Intercountry Adoption ('Hague Convention'), which was adopted with the aim to tackle illegal and commercial practices within the intercountry adoption system, ${ }^{7}$ prohibits them

* Elvira Loibl is Assistant Professor Criminal Law and Criminology, Universiteit Maastricht.

1 D.M. Smolin, 'Child Laundering: How the Intercountry Adoption System Legitimizes and Incentivizes the Practices of Buying, Trafficking, Kidnapping, and Stealing Children', The Wayne Law Review 2016 vol. 52, p. 113-200.

2 Ibid.

3 N. Cantwell, 'Is intercountry adoption linked with trafficking for exploitation?', International Social Service 2005 no. 11-12, p. 1-2.

4 Ibid.

5 E. Loibl, The Transnational Illegal Adoption Market: A Criminological Study of the German and Dutch Intercountry Adoption Systems, The Hague/Chicago: International Publishing Eleven 2019, p. 4750 .

6 Ibid., p. 152-156.

7 Art. 1b) Hague Convention. 
and provides that they cannot be recognized. ${ }^{8}$ However, in practice, Article 3(1) of the UN Convention on the Rights of the Child ('UNCRC'), and Article 8 of the European Convention on Human Rights ${ }^{9}$ ('ECHR'), often make it difficult for the authorities in the receiving countries to properly respond to private adoptions. ${ }^{10}$ Once the privately adopted child has lived with the new family for a particular period of time and, thus, has already bonded with the adoptive parents, refusing to recognize or grant an adoption or removing the child from the care of the adopters is usually considered incompatible with the best interests of the child and the right to respect for private and family life.

In 2017, the European Court of Human Rights ('ECtHR') rendered a judgment in Campanelli and Paradiso v. Italy. ${ }^{11}$ In this case, the Court dealt with the question as to whether removing a child from the care of an Italian couple that entered into a surrogacy agreement with a Russian clinic, given that surrogacy is illegal in Italy, violated Article 8 ECHR. Contrary to previous case law, in which the ECtHR placed a strong emphasis on the best interests of the individual child concerned, ${ }^{12}$ the Court attached more weight to the need to prevent disorder and crime by putting an end to the illegal situation created by the Italian couple and by discouraging others from bypassing national laws. ${ }^{13}$

This article examines the judgment's implications for privately arranged international adoptions. It shows that although private adoptions are closely linked to abusive and commercial practices and violate both national and international law, they are commonly recognized by German and Dutch family courts claiming that this ultimately serves the rights and best interests of the individual child concerned. National courts dealing with cases of private intercountry adoptions face a dilemma: on the one hand, leaving the child with the new family and recognizing the private adoption essentially legitimizes the placement of a child that took place in circumvention of the legal adoption procedure and potentially invites prospective adopters to pursue an adoption without the involvement of an agency; on the other hand, removing the child from the family might violate his or her individual rights and interests. This article argues that considering the shifting focus of the ECtHR in Campanelli and Paradiso v. Italy on the prevention of unlawful conduct and, thus, on the best interests of children in general, the German and Dutch case law on private adoptions, which seems to prioritize the best interests of the particular child, is difficult to hold in the future. Instead, the courts are required to

8 Art. 29 Hague Convention; The Permanent Bureau of the Hague Conference on Private International Law, The Implementation and Operation of the 1993 Hague Intercountry Adoption Convention: Guide to Good Practice No. 1, 2008, p. 16.

9 Council of Europe, European Convention on Human Rights - Convention for the Protection of Human Rights and Fundamental Freedoms, Rome, 4.XI.1950 (ECHR).

10 Loibl 2019, p. 416-418.

11 ECHR 24 January 2017 (Campanelli and Paradiso v. Italy), no. 25358/12.

12 ECHR 26 June 2014 (Mennesson v. France), no. 65192/11; ECHR 26 June 2014 (Labassee v. France), no. 65941/11.

13 L. Bracken, 'Assessing the best interest of the child in cases of cross-border surrogacy: inconsistency in the Strasbourg approach?', Journal of Social Welfare and Family Law 2017 vol. 39, no. 3, p. $368-379$. 
engage in a more balanced assessment of the different rights and interests involved.

The focus on Germany and the Netherlands is interesting for several reasons. Both are recipients of foreign adoptees and have ratified the UNCRC as well as the Hague Convention. Since both, Germany and the Netherlands, therefore, ratified the international standards and procedures concerning foreign adoptions, their adoption laws and policies are similar in many respects. However, the countries differ greatly in the way they approach private international adoptions. In Germany, privately pursued adoptions are not explicitly prohibited by law, which might be one of the reasons why such a high number thereof can be observed. Dutch law, by way of contrast, bans adopters from adopting a child from abroad without the involvement of an accredited agency and the Dutch authorities. However, as will be shown in this article, despite the significant difference in laws, both countries generously recognize private international adoptions in practice.

The article is composed of five sections. Section 2 describes private intercountry adoptions and explains why they are closely connected to abusive and illegal practices. Section 3 examines German and Dutch case law on private adoptions. Section 4 discusses the ECtHR's groundbreaking judgment in the case of Campanelli and Paradiso v. Italy from 2017 and describes the Court's shifting focus from the best interests of the child in previous case law to the prevention of unlawful conduct. Section 5 discusses the implications of the ECtHR's judgment for private adoptions and section 6 concludes this article.

\section{Private intercountry adoptions and abusive practices}

Private adoptions - also referred to as independent adoptions - are directly arranged between the adopters and the birth parents or the organization caring for the child (e.g. orphanage). They take place without the involvement of an adoption agency in the receiving country that would assess the adopters' suitability to adopt a child and guide them through the adoption process. Adopters usually decide to pursue a private adoption because they want to circumvent the usually very lengthy and cumbersome official adoption procedure and/or because they do not meet the adoption requirements (e.g. age limits). ${ }^{14}$ They might use an unauthorized private contact (e.g. such foreign social worker, nurse, doctor, or attorney) in the sending country, acting as an intermediary which often offers a shortening or circumvention of the time-consuming official adoption placement procedure. They locate a child, secure the necessary consent to an adoption and prepare the adoption paperwork. ${ }^{15}$

Private adoptions are strongly linked to abuses and irregularities. A study that was conducted in Germany in the late 1980s shows a clear link between private adop- 
tions and illegal practices. ${ }^{16}$ It evaluated data about 300 adoption cases of intercountry adoptions from developing countries carried out between 1984 and 1987 in four Western German states. Only 134, thus approximately 45\%, took place via a German international adoption placement office. As for the other 55\%, parents obtained their children through personal contacts or with the help of commercial organizations or individuals. ${ }^{17}$ In 70 of these 300 cases "clear indications of commercial, illegal or criminal practices" could be found, meaning that " $23 \%$ of all adoptions of children from the Third World or $42 \%$ of all private adoptions are violating the adoption laws of the Federal Republic of Germany and - in general those of the sending countries" ${ }^{18}$ Moreover, in a great number of private adoption cases, the required documents (e.g. the relinquishment decree, the child's birth and health certificate, the social report and the administrative or judicial decisions) deviated significantly from the documents in agency adoptions. They were often incomplete, unclear and would not comply with the sending countries' laws. ${ }^{19}$

In addition, more recent experiences in, for instance, Guatemala have shown that privately organized intercountry adoptions are closely linked to illegal and abusive practices. ${ }^{20}$ In this sending country, international adoptions were generally processed under a 'notarial system'. ${ }^{21}$ Adopters would hire a private attorney representing the prospective adoptive parents, the birth parents as well as the child. The primary review of the adoption case was then conducted by the Guatemalan Solicitor General's Office. ${ }^{22}$ Although Guatemala was and still is a developing country with about $39 \%$ of the population living below $\$ 2$ a day, ${ }^{23}$ the fees paid to the Guatemalan attorneys were inordinate, ranging between $\$ 18,000$ and $\$ 19,000 .{ }^{24}$ Between 2003 and 2010, the country sent some 24,000 children for adoption, constituting the third most significant supplying state after China and Russia. ${ }^{25}$ Soon it became clear that "legal adoption appears to be the exception rather than the rule" ${ }^{26}$ In her report on the mission to Guatemala, the Special Rapporteur on the sale of children, child prostitution and child pornography concluded that: "In the

16 R.P. Bach, 'Daten und soziale Hintergründe der Adoption von Kindern aus der Dritten Welt. Eine Untersuchung der Gemeinsamen Zentralen Adoptionsstelle der vier norddeutschen Bundesländer in Hamburg', Zentralblatt für Jugendrecht 1988 vol. 75, p. 328-333.

17 Ibid., p. 332.

18 Ibid. (According to Bach, an adoption is considered commercial when financial rewards are granted to a person having the care and custody of a child (birth parent, warden or director of an orphanage) in exchange for the required consent to the adoption (deed of relinquishment). Adoptions are illegal when they violate civil or administrative legal provisions and they are criminal when they constitute a criminal offence, such as child abduction, falsification of documents or child trafficking.)

19 Ibid.

20 Loibl 2019, p. 159-161.

21 Smolin 2016, p. 164-167.

22 Ibid.

23 The World Bank, 'World Development Indicators', 2013 available at http://databank.worldbank. org/data/download/wdi-2013-ebook.pdf, p. 28.

24 Smolin 2016, p. 164.

25 P. Selman, 'The Global Decline of Intercountry Adoption: What Lies Ahead?', Social Policy and Society 2012 vol. 11, no. 3, p. 381-397.

26 UN Commission on Human Rights, Report of the Special Rapporteur on the Sale of Children, Child Prostitution and Child Pornography, 2000, 27.01.2000, E/CN.4/2000/73/Add.2, para. 13. 
majority of cases, intercountry adoption involves a variety of criminal offences including the buying and selling of children, the falsifying of documents, the kidnapping of children, and the housing of babies awaiting private adoptions in homes and nurseries set up for that purpose". ${ }^{27}$ Attorneys would, for instance, "buy babies while they are still in the mothers' womb", ${ }^{28}$ "trick[ing] or drug[ging] illiterate birth mothers into putting their thumbprint on blank pieces of legal paper which are subsequently filled in to read as a consent to adoption of the baby", ${ }^{29}$ "use middlemen to seek out pregnant women who, because of poverty or prostitution, might be willing to give up their children or to sell them" 30 and who would "resort to threats or even baby-stealing" if the mother could not be persuaded. ${ }^{31}$

It is worth noting that the official adoption placement procedure is not a warrant against illegal practices and that agency adoptions are not ipso eo free from abuses either. Within the past couple of years, irregularities were also uncovered in adoptions carried out with the involvement of an accredited agency. Many adoption agencies have a strong ideological as well as financial motivation to 'rescue' as many children as possible. This motivation potentially creates an incentive to cut ethical corners, for instance, by ignoring signs of abusive practices in the sending countries or by failing to properly limit and control the costs paid for an adoption. ${ }^{32}$ However, as Bach's study from 1988 suggests, private adoptions are particularly prone to commercial and illegal practices. Privately arranged adoptions take place without there being any supervision and control whatsoever. The authorities in the recipient state, if at all, only obtain knowledge of the international adoption after the child has been transferred to the receiving country: when the adopters want to register the child, apply for an adoption or want a foreign adoption judgment recognized. The authorities do, therefore, not have the opportunity to check the adoption documents and to prevent the child from entering the receiving country in case they suspect abuses or irregularities in the adoption. ${ }^{33}$ Furthermore, private adopters are often not sensitized to the risks involved in an intercountry adoption procedure. They might directly contact the child's parents or make donations to the biological family or the orphanage caring for the child, unaware of the harm that they thereby create. ${ }^{34}$

The 1993 Hague Convention on Protection of Children and Co-operation in Respect of Intercountry Adoption (hereinafter Hague Convention) prohibits private adoptions due to the high risks involved in them. The treaty established the competent authorities' principle, which provides that all intercountry adoptions must be channeled through the Central Authorities, both in the sending and the receiving country. ${ }^{35}$ In addition, its Article 29 prohibits contact between adopters and the child's parents or the person or institution caring for the child before the offi-

27 Ibid.

28 Ibid., para. 33.

29 Ibid., para. 35.

30 Ibid., para. 36.

31 Ibid., para. 38.

32 Loibl 2019, p. 418-421.

33 Loibl 2019, p. 416.

34 Ibid.

35 Art. 1b), Art. 6 Hague Convention. 
cial matching takes place. The Convention's Guide to Good Practice No 1. emphasizes that adoptions directly arranged between birth parents and adoptive parents are not compatible with the Convention and can never be recognized. ${ }^{36}$ Such adoptions, the Guide stresses, would "undermine the system of safeguards put in place by the Convention, in particular Article 29". ${ }^{37}$ It is not uncommon that money (maybe in the form of 'donations' or 'facilitation payments') change hands in a private adoption, which might then also bring the facts of the case within the ambit of the Optional Protocol to the UNCRC on the sale of children, child prostitution and child pornography. ${ }^{38}$ Private adoptions also violate the national regulations of the receiving country: the adopters circumvent the official adoption placement procedure provided by law by adopting a child without the involvement of an accredited adoption agency and without the authorization of the Central Authority in their home country. In addition, their actions might fall within the scope of the criminal law, for instance, if they forged adoption documents, paid money to the child's birth parents or the institution caring for the child or if they smuggled the child into their home country without the required travel documents.

Yet, although private adoptions clearly violate both international and national law, the authorities in the receiving countries often recognize such adoptions, referring to the best interests of the child concerned and the right to private and family life.

\section{Art. 3 UNCRC and Art. 8 ECHR in German and Dutch jurisprudence on private adoptions}

In Germany, intercountry adoptions that took place in circumvention of the official adoption placement procedure are widely tolerated. A study from 2007 revealed that $90 \%$ of foreign decisions on an adoption, that took place independently, were recognized by German courts. ${ }^{39}$ The courts would commonly assess the adopters' suitability to adopt the child at the time of the recognition procedure and - after a positive evaluation - determine that the foreign adoption judgment is to be recognized. ${ }^{40}$ The best interests of the child, laid down in Article 3(1) UNCRC, as well as the right to respect for family and private life, according to Article $8 \mathrm{ECHR}$, make it difficult for the courts to refuse recognition. ${ }^{41}$

This jurisprudence finds further support in a judgment of the German Federal Court of Justice from 2014. ${ }^{42}$ Even though the judgment dealt with surrogacy, the Court's observations on the child's best interests were subsequently applied to cas- 
es of intercountry adoption. ${ }^{43}$ In this case, a German same-sex couple entered into a surrogacy agreement with a woman from California. Whereas one of the men was the child's genetic father, the egg originated from an anonymous donor. After the child was born, a court in California deemed the German couple to be the legal parents in accordance with domestic law. The German Federal Court of Justice had to deal with the question as to whether the Californian court judgment had to be recognized although surrogacy is illegal in Germany. Even though it had been settled case law that foreign judgments establishing legal parenthood of intended parents were manifestly contrary to German public policy, the Federal Court of Justice found that the Californian decision had to be recognized. It argued that the child's right to family life laid down in Article 8 ECHR would be infringed if the Californian court decision were not recognized according to German law. ${ }^{44}$ This is because refusing to recognize would mean that the child, who was given up by the surrogate mother, only had one legal parent: the biological father. ${ }^{45}$ Most importantly, the Court stated that both, Article 8 ECHR and the principle of the child's best interests, would generally preclude that the recognition of a foreign decision be refused "only due to the general preventive consideration that (further) circumventions of the ban on surrogacy agreements can thereby be prevented". ${ }^{46}$ In other words, the recognition cannot be refused only because this might prevent others from pursuing a surrogacy agreement.

Some German family courts that had to decide on the recognition of a foreign adoption decision already referred to the judgment of the German Supreme Court from 2014 and its reasoning. For example, the Higher Regional Court Celle had to deal with the question as to whether an adoption agreed upon by the adopters and the child's biological parents "during a festive adoption ceremony" without there being a German accredited adoption agency involved had to be recognized. ${ }^{47}$ Even though the adopters' suitability to adopt had not been assessed, neither in Germany nor in the child's country of origin, the German Court decided to recognize the foreign adoption decision. It stated that a violation of the standards of the Hague Convention would not per se justify refusing the recognition of a foreign adoption decision. Referring to the judgment of the German Supreme Court from 2014, the Court Celle stated:

"General preventative considerations referring to the objective of the Hague Convention to ensure that, by an advanced co-operation amongst the Contracting States and agreed up procedural standards, intercountry adoptions are made in the best interests of the child and with respect for his or her fundamental rights, and to prevent the abduction, the sale of, or traffic in children, cannot justify a violation of the best interests of the particular child involved. [...] It must not be to the detriment of the individual child that the 
biological parents and the adopters - intentionally or unintentionally - circumvented the procedure provided by the Hague Convention." ${ }^{48}$

The Court Celle argued that the child's right to family life, according to Article 8 ECHR, as well as his best interests, would be violated if the foreign adoption decision were not recognized. ${ }^{49}$ This is because refusing to recognize the foreign adoption decision would leave the child in legal uncertainty: on the one hand, he is denied a legal relationship with the adopters in Germany, with whom he had already bonded, and might even have to leave the country, as he would lose his residency status. In his country of origin, on the other hand, he would not be able to return to his biological parents as they had relinquished their parental rights. ${ }^{50}$ The child would, thus, be left without (legal) parents, which cannot be considered to be in his best interests.

In the Netherlands, family courts face the same dilemma. Unlike in Germany, Dutch law explicitly states that a foreign court decision on an adoption that was pursued privately cannot be recognized. ${ }^{51}$ In addition, Dutch family courts may place the privately adopted child in another family or even send the child back to the country of origin. ${ }^{52}$ However, this measure may only be ordered if it is compatible with the best interests of the child. In 2000, the Dutch Supreme Court ruled that a child could remain with the adopters despite them having maliciously violated Dutch adoption law..$^{53}$ In this case, a Dutch couple travelled to the Philippines where they found an adoptable child with the help of a private contact. After the adopters had the child's birth certificate issued indicating them as the biological parents, they brought the child to the Netherlands. The illegal activities were uncovered after someone gave an anonymous tip to the Dutch police. The court in Eindhoven left the child with the adopters, arguing that it would not be in her best interests to be removed and then placed with another family. The decision was confirmed by the court in the second instance and finally also by the Dutch Supreme Court. The latter ruled that it falls within the court's discretion to decide on removing the child from the adopters and that this measure must take the child's best interests into consideration. ${ }^{54}$ This means, the Court argued, that the child cannot be placed into another family if there is a real risk that he or she will suffer physical or psychological harm.

In several cases, Dutch courts decided to leave the child within the new family and grant either an adoption or at least interim guardianship (if the adopters have engaged in particularly objectionable actions)..$^{55}$ For example, in a spectacular case involving a surrogate baby called Donna from Belgium, the Court Utrecht decided to leave the child with the Dutch couple that illegally brought her to the Nether- 
lands. It argued that a de facto bond emerged between the child and the Dutch couple, which amounted to family life according to Article 8 ECHR. ${ }^{56}$ The Dutch couple bought the child online and then brought her to the Netherlands for the purpose of care without involving the Dutch authorities. The child's biological mother acted as a surrogate for a Belgian couple and offered the child on the internet after having had an argument with the intended parents. The court in Utrecht ruled that the child should remain with the Dutch couple, ruling that a family life bond had emerged between them and the baby, for whom they had continuously cared ever since her birth. ${ }^{57}$ A couple of months later, the court in Utrecht finally granted the Dutch couple guardianship of the child. ${ }^{58}$

The best interests of the children concerned and the right to family life, according to Article 8 ECHR seem to make it impossible for the authorities in Germany and the Netherlands to end the unlawful situation created by private adopters, by refusing to recognize the private adoption and by removing the child from the new family. However, the considerations of the ECtHR in a recent judgment on surrogacy offer a new approach to dealing with private intercountry adoptions.

\section{Campanelli and Paradiso v. Italy - Shifting the focus from the best interests of the child to prevention of unlawful conduct}

In 2017, the ECtHR issued a groundbreaking judgment in the case of Campanelli and Paradiso v. Italy, which concerned the removal of a surrogate-born child from his intended parents. ${ }^{59}$ In May 2010, an Italian couple, Mr. Campanelli and Mrs. Paradiso, contacted a Russian surrogacy clinic since surrogacy is illegal in Italy. The clinic found a surrogate mother and then delivered the baby boy with a birth certificate indicating the applicants as the child's biological parents for a total of $€ 50,000$. Based on the child's birth certificate, the Italian Consulate in Moscow issued the documents that enabled him to enter Italy and informed the authorities in Italy that the child's paperwork contained false information.

In May 2011, the Italian prosecutor's office opened criminal proceedings against the couple for misrepresentation of civil status, use of falsified documents as well as for violation of the Italian Adoption Act since they brought the child to Italy without the authorization of the Commission for Intercountry Adoption. In parallel, the Minors Court appointed a guardian and opened proceedings to make the child available for adoption. Since the child's real parents were unknown, he was legally considered in a 'state of abandonment', i.e. deprived of all support from his parents or family members. Following the appointment of the legal guardian, the registration of the Russian birth certificate was refused. In the proceedings before the Minors Court, a team of social workers drew up a report indicating that the applicants were respected citizens that had a comfortable income and lived in a

58 P. Dorhout, 'Baby Donna, waar ging het mis?', Tijdschrift voor Familie- een Jeugdrecht 2008 vol. 7/8, no. 70.

59 ECHR 24 January 2017 (Campanelli and Paradiso v. Italy), no. 25358/12. 
nice house and that the child was in excellent health and being cared for by the applicants to the highest standards.

The couple believed that Mr. Campanelli was the child's biological father, whereas the egg came from an anonymous donor. However, DNA testing ordered by the court showed that there was no genetic link between the child and the couple, revealing an error in the clinic. The applicants asked for the child to be placed with them, with a view to adopting him if necessary. They asked a psychologist to draw up a report on the child's well-being. This report indicated that the applicants who were attentive to the child's needs had developed a deep emotional bond with him. It concluded that the applicants were suitable parents and that a removal would have devastating consequences for the child who would go through a depressive phase on a count of the loss of the key persons in his life.

Yet, in October 2011, the child was removed from the applicants and placed in a children's home for fifteen months, before ending up in a new family. All contact between the applicants and the child was prohibited. In its decision, the Minors Court considered the fact that the applicants had acted unlawfully and that it was, therefore, "necessary, above all, to prevent this unlawful situation from continuing, since to maintain it would be equivalent to ratifying unlawful conduct in open violation of the provisions of our legislation". ${ }^{60}$ It recognized that the child would suffer harm from the separation, but, given the short period spent with the applicants and his young age, it considered that this trauma would not be irreparable as claimed by the psychologist. It argued that the applicants' unlawful conduct gives rise to the fear that the child resulted from a narcissistic desire, which would cast doubt on their emotional and educational abilities. Hence, the court considered the separation in the child's best interests.

Ultimately, the couple brought their case to the ECtHR alleging that the measures taken in respect of the child violated their right to respect for private and family life, according to Article 8 ECHR. The Chamber found that the relationship between the applicants and the child amounted to de facto family life within the meaning of Article 8 ECHR, taking into account the fact that the applicants had shared with the child the first important stages of his life and that they had acted as parents towards the child. It concluded that the child's removal from the intended parents constituted an interference with de facto family life, which amounted to a violation of Article 8 ECHR as the authorities did not properly balance between the general interests and the private interests at stake. ${ }^{61}$ The Italian Government subsequently requested that the case be referred to the Grand Chamber of the ECtHR.

In contrast to the conclusion of the Chamber, the Grand Chamber did not find that de facto family life existed in the present case. It reiterated that Article 8 ECHR does not involve the right to found a family or to adopt a child (e.g. Fretté v. France, ${ }^{62}$ Pini and Others v. Romania ${ }^{63}$ ), but the right to respect an existing family life. Family life, the ECtHR asserted, does not only exist between married parents and their biolog- 
ical or de jure (legally adopted) children but also between family members who are legally and biologically unrelated if they have close de facto ties (e.g. $X, Y$ and $Z v$. $\left.U K^{64}\right)$. The Court would consider the quality of the personal ties, the role played by the applicants vis-à-vis the child as well as the duration of the cohabitation between them and the child (Moretti and Benedetti v. Italy, ${ }^{65}$ Kopf and Liberda v. Austria, ${ }^{66}$ Wagner and J.M.W.L. v. Luxemburg, ${ }^{67}$ D. and Others v. Belgium $\left.{ }^{68}\right) .{ }^{69}$ The ECtHR considered that the applicants had assumed their role as parents and had forged close emotional bonds with the child. However, it asserted that the duration of the period in which the applicants lived together with the child, namely eight months, was too short to establish a de facto family life. ${ }^{70}$ In addition, the applicants' illegal conduct, which created the situation of legal uncertainty, constituted another reason for rejecting family life. ${ }^{71}$

However, the Grand Chamber accepted that the state's actions constituted an interference with the right to private life. This right, the Court reiterated, encompasses inter alia the right to establish and develop relationships with other human beings, the right to personal development, the right to self-determination, and the right to respect for the decision to become parents (e.g. Pretty v. UK ${ }^{72}$, Evans $v$. $\left.U K^{73}\right) .^{74}$ The Court held that the applicants' endeavor to realizing their plan to become parents fell into the scope of the right to private life which was interfered with by the child's removal from the applicants. ${ }^{75}$ However, the removal served to protect important public interests, which weigh more heavily than the applicants' interest in their personal development by continuing their relationship with the child. First, the measure was intended to ensure the "prevention of disorder and crime' (Art. 8(2) ECHR) by bringing the illegal activities of the parents to an end and deterring others from bypassing the national laws. Second, it aimed to protect the children's rights and freedoms as required by Article 3 UNCRC - not only of the individual child in the present case (who was deemed to be in a 'state of abandonment') but also of children more generally. ${ }^{76}$ The ECtHR concluded: "Agreeing to let the child stay with the applicants, possibly with a view to becoming his adoptive parents, would have been tantamount to legalizing the situation created by them in breach of important rules of Italian law." ${ }^{77}$ Accepting that the Minors Court struck a fair balance between the different interests at stake, the Chamber ruled that there was no violation of Article 8 ECHR. 
The ECtHR's judgment in Campanelli and Paradiso v. Italy was preceded by an intense internal debate at the Court. The four concurring opinions following the judgment illustrate the highly controversial character of surrogacy as a newly emerging form of family formation as well as the complex interplay between the differing interests involved that raises difficult ethical and moral questions. Some judges criticized the Chamber for not having taken a clear stance against surrogacy as an illegal practice incompatible with the values of the ECHR. They argued that it amounts to the sale of children according to international law, most notably the 1993 Hague Convention and the Optional Protocol to the UNCRC on the sale of children, child prostitution and child pornography, and that it is incompatible with human dignity as "both the child and the surrogate mother are treated not as ends in themselves, but as means to satisfy the desires of other person" ${ }^{78}$ Other judges, however, rejected the Chamber's conclusion that there has been no violation of Article 8 ECHR. They criticized the Court for distinguishing between "legitimate" and "illegitimate" families and thereby rejecting the long-established principle that the existence of family life is a question of fact. ${ }^{79}$ According to them, the Chamber has put too much weight on the prevention of disorder and crime, whereas the interests of the child and the parents were not sufficiently taken into account. ${ }^{80}$ Considering the ECtHR's previous case law on surrogacy, a shifting focus can indeed be identified. The Court initially took a mainly child-centered approach in cases concerning surrogacy, acknowledging that children should not be disadvantaged due to the circumstances of their birth. ${ }^{81}$ In Mennesson v. France ${ }^{82}$ and Labassee v. France ${ }^{83}$ - two ECtHR judgments, which constituted the leading cases on this topic - the best interests of the children concerned led the Court to find a violation of Article $8 \mathrm{ECHR}$, notwithstanding the fact that the intended parents unlawfully pursued gestational surrogacy abroad. In both cases, the intended fathers were also the children's genetic fathers. The US court declared the intended parents to be the children's legal parents. However, the French courts declined to recognize the US court judgment arguing that it was contrary to French public policy, considering that surrogacy is prohibited in France. In Mennesson v. France, ECtHR found that both family life and private life existed between the applicants and the children. It concluded that the interference into the applicants' right to respect for family life did not amount to a violation of Article 8 ECHR as the applicants were able to live together with the children in France and there was nothing to suggest that the children would be removed from them. ${ }^{84}$

However, the Court found a violation of the applicants' right to respect for private life. This right, it reiterated, requires that "everyone should be able to establish details of their identity as individual human beings, which includes the legal par-

ECHR 24 January 2017 (Campanelli and Paradiso v. Italy), no. 25358/12, Joint Concurring Opinion of Judges De Gaetano, Pinto De Albuquerque, Wojtyczek and Dedov, para. 6-7.

79 ECHR 24 January 2017 (Campanelli and Paradiso v. Italy), no. 25358/12, Joint Dissenting Opinion of Judges Lazarova, Trajkovska, Bianku, Lafranque, Lemmens and Grozev, para. 4.

80 Ibid., para. 12.

81 Bracken 2017, p. 370.

82 ECHR 26 June 2014 (Mennesson v. France), no. 65192/11.

83 ECHR 26 June 2014 (Labassee v. France), no. 65941/11.

84 ECHR 26 June 2014 (Mennesson v. France), no. 65192/11, para. 92. 
ent-child relationship". ${ }^{85}$ The Court noted that the children at the center of the cases were in 'a position of legal uncertainty': they could not acquire French nationality and were deprived of their inheritance rights. The Court accepted that the French authorities wished to deter its nationals from going abroad to access surrogacy. Yet, it found that the refusal to recognize the parent-child relationship did not only have consequences for the intended parents but also for the children whose right to respect for private life and ability to establish the substance of their identity were substantially affected. ${ }^{86}$ These issues took on a "special dimension" given that the intended father was also the genetic father. ${ }^{87}$ Considering the importance of biological parentage as a component of identity, the ECtHR concluded that it was not in the best interests of the child to deprive him of a legal relationship of this nature where the biological reality of that relationship has been established. The ECtHR adopted the same line of reasoning in Labassee v. France, finding a violation of the right to private life according to Article 8 ECHR. ${ }^{88}$ In its first ever Advisory Opinion, delivered in 2019 upon request of the French Court of Cassation, the Court also strengthened the legal position of the intended mother in a situation where a foreign-born surrogate child was conceived using the gametes of the intended father and a third-party donor, and where the legal parent-child relationship with the intended father has been recognized in domestic law. It noted that "the child's right to respect for private life also requires domestic law to provide for a possibility of recognition of a legal parent-child relationship with the intended mother, designated in the birth certificate legally established abroad as the 'legal mother'." 89

Whereas in the French cases, the ECtHR placed a strong emphasis on the best interests of the children concerned, in Campanelli and Paradiso v. Italy, the Court attached more weight to the need to put an end to an illegal situation and to discourage other citizens from engaging into surrogacy. The absence of a biological link between the intended parents and the child was the determining feature that distinguished Campanelli and Paradiso v. Italy from earlier cases..$^{90}$ In the French cases, the intended father was the child's biological father: his gametes were used in the in-vitro-fertilization procedure carried out abroad. In the Italian case, however, the child and the intended parents were genetically unrelated. The existing biological ties are, thus, a significant factor in the assessment as to whether or not the right to respect for private life has been violated. Where the biological link is lacking, the ECtHR will be slower to find an infringement of Article 8 ECHR. This, notwithstanding the Court's long-established principle that the existence of family life is a question of fact and not law. ${ }^{91}$

89 ECHR, Advisory Opinion Concerning the Recognition in Domestic Law of a Legal Parent-Child Relationship Between a Child Born Through a Gestational Surrogacy Arrangement Abroad and the Intended Mother, 10 April 2019, Request no. P16-2018-001 by the French Court of Cassation.

90 Bracken 2017, p. 373.

91 Ibid. 
The ECtHR's shift may be explained by the growing concern about the global surrogacy industry. Whereas the number of intercountry adoption has been declining since 2004, commercial surrogacy has rapidly expanded over the past couple of years. Numerous human rights experts have criticized this newly emerging phenomenon as a form of discrimination against women who are vulnerable to exploitation due to poverty, powerlessness and a lack of education. Surrogacy arrangements as currently practiced violate the rights of children, including their right to acquire a nationality and, as far as possible, the right to know and be cared for by his or her parents, ${ }^{92}$ their right to identity, ${ }^{93}$ and the right to not be separated from their parents against their will ${ }^{94}$ and take place in total disregard of the children's best interests. In addition, such arrangements amount to the "sale of children" under international law as it involves the transfer of a child for remuneration. ${ }^{95}$ This is why most jurisdictions either ban surrogacy altogether (e.g. France and Germany) or prohibit at least commercial surrogacy (e.g. UK, Greece). ${ }^{96} \mathrm{How}$ ever, a small minority of states permit commercial surrogacy (e.g. Ukraine, India, US) which have become hotspots for "surrogacy tourism". ${ }^{97}$ Intended parents would evade the prohibitionist laws of their home states by travelling to jurisdictions that permit commercial surrogacy and then return with surrogate-born children. ${ }^{98}$ The authorities and courts in the parents' home jurisdiction do often not see any other option than to validate, after the fact, international surrogacy arrangements that are illegal. The imperative to protect the rights and interest of surrogate-born children make it difficult to remove the children from the intended parents and thereby essentially serve the latter as a shield from any repercussion for their actions.

Some commentators welcomed the ECtHR's recent judgment in Campanelli and Paradiso $v$. Italy for sending out a discouraging message to couples who seek to form a family by engaging into illegal practices. ${ }^{99}$ Others, however, strongly criticized the Court's findings. They claim that the ECtHR's approach is arbitrary as it protects intended parents who have a biological link with the surrogate-born child vol. 43, p. 265-344; J. Tobin, 'To prohibit or to permit: what is the (human) rights response to the practice of international commercial surrogacy?', International and Comparative Law Quarterly 2014 vol. 63, no. 2, p. 317-352.

96 Human Rights Council, Report of the Special Rapporteur on the sale and sexual exploitation of children, including child prostitution, child pornography and other child sexual abuse material, 26 February-23 March 2018, A/HRC/37/60.

97 Ibid.

98 Ibid.

99 See, e.g., E. Ignovska, 'Paradiso and Campanelli v. Italy: Lost in Recognition. Filiation of an Adopted Embryo born by Surrogate Woman in a Foreign Country', Strasbourg Oberservers, 04 April 2017, available at https://strasbourgobservers.com/2017/04/04/paradiso-and-campanelli-v-italy-lost-in-recognition-filiation-of-an-adopted-embryo-born-by-surrogate-woman-in-a-foreigncountry/ (last accessed on 30.11.2020). 
while it only discourages those that do not use their genetic material for the embryos implanted in the surrogate mother. ${ }^{100}$

\section{Implications of Campanelli And Paradiso v. Italy for private intercountry adoptions}

The case of Campanelli and Paradiso v. Italy concerned a surrogate-born child that had no genetic link to either of the intended parents. The ECtHR's observations and conclusions can, therefore, also be applied to cases of international adoption where there is no biological connection between the child and the adopters either. Like illegal surrogacy arrangements, private international adoptions are in violation of both international and national law. And in both, illegal surrogacy arrangements and private international adoptions, the dichotomy between the interest to sanction and prevent bypassing the law, on the one hand, and the rights and best interests of the individual child, on the other hand, is central.

The current case law on private intercountry adoptions in Germany and the Netherlands seems to prioritize the rights and best interests of the individual child over the broader interests to sanction and prevent illegal behaviour by adopters. The courts tend to leave a privately adopted child with the adopters that violated legal rules but generally seem to be suited to care for the adoptee, arguing that removing the child from the family environment would not be in the best interests of the child concerned and would violate the right to respect for private and family life laid down in Article 8 ECHR. The courts either recognize the foreign court decision on a private adoption, or they grant adoption or at least interim guardianship.

Is leaving the child with adopters that violated legal rules, really in his or her best interests and necessary in view of Article 8 ECHR? Like in the case of Campanelli and Paradiso v. Italy, adopters can usually be considered fit to properly care for the adopted child: they are financially well off, have the necessary means to provide for the adoptee and are prepared to love the adopted child as a biological one. ${ }^{101} \mathrm{Re}$ moving the privately adopted child from the adopters he or she has lived together with for a certain period of time and placing the adoptee with a new family will likely cause trauma and harm to the child that has developed a strong emotional bond with the caretakers. A separation would violate the right to respect for family life laid down in Article 8 ECHR, which, according to ECtHR case law, does not only protect legally established relationships between children and their parents but also close de facto family ties. Placing the child into a new family might only be compatible with his or her individual interests and rights in cases where the irregular circumstances of the adoption were discovered shortly after the placement took place - meaning that the child has not lived with the caretakers long enough

100 See, e.g., M. Iliadou, 'Commentary: Surrogacy and the ECtHR: Reflections on Paradiso and Campanelli v Italy', Medical Law Review 2018 vol. 27, no. 1, p. 144 -154; M.N. Shúilleabháin, 'Surrogacy, System Shopping, and Article 8 of the European Convention on Human Rights', International Journal of Law, Policy and The Family 2018 vol. 33, p. 104-122.

101 This is also the reason why trafficking children for the purpose of adoption is not considered a form of human trafficking which requires exploitation of the child as the purpose. 
for an emotional bond to emerge - or where the adoptee is still too young to actually realize the separation.

However, legally recognizing a private adoption without any effort being made to clarify the true circumstances of the placement arguably violates another right protected by Article 8 ECHR: the adoptee's right to know his or her origins. Many adoptees develop a strong desire to know where they come from and how their adoption took place once they have grown up. Article 7 UNCRC provides them with the right to discover their origins, which is to be understood in relation to the more general right to preserve one's identity laid down in Article 8 UNCRC. This right is an essential part of the right to respect for private life and has been derived by the ECtHR directly from Article 8 ECHR. ${ }^{102}$ The right to identity preservation is of particular importance when the child is separated from the parents. ${ }^{103}$ Simply recognizing a private adoption without investigating as to how the placement took place interferes with this right. First, it makes it difficult for the adoptees to investigate their origins as adults, years later when information about their adoptions is more difficult to obtain. In addition, it might provide the private adopters with a sense of legitimacy: legally recognizing legal ties that have been brought about by illegal behaviour might make them feel that their actions were legitimate and that there is no need to explain themselves or provide information about the adoption placement procedure once the adopted individual is old enough to question his or her adoption.

Leaving the child with the private adopters might in some cases be in his or her best interests. Yet, it is harmful to the interests of children in general. ${ }^{104}$ The generous jurisprudence on private adoptions in Germany and the Netherlands can be described as inviting couples and individuals to adopt independently. ${ }^{105}$ It rewards adopters who pursue a more rapid and less bureaucratic private adoption while sanctioning those that undergo the lengthy and cumbersome official adoption placement procedure. By allowing adopters to keep the illegally adopted child and by recognizing the private adoption, the family courts essentially legalize the situation created by them in breach of legal rules. Private adopters may be fined for having violated national adoption regulations. ${ }^{106}$ However, considering the large sums of money that prospective adoptive parents are willing to pay for a child to love, a monetary fine will hardly have any deterrent effect as long as they get to keep the illegally adopted child. ${ }^{107}$ The longer the child has lived with the private adopters, the stronger the emotional bond between them, the harder it is for the courts to remove the child from the family. Hence, adopters who hide the child

102 S. Besson, 'Enforcing the child's right to know her origins: Contrasting approaches under the convention on the rights of the child and the European convention on human rights,' International Journal of Law, Policy and the Family 2007 vol. 21(2), p. 137-159.

103 See UN Committee on the Rights of the Child (2006), 'Report on the 40th session', 17 March 2006, CRC/C/153, para. 680 .

104 Loibl 2019, p. 302.

105 E. Loibl, 'The German and Dutch intercountry adoption systems: weaknesses that facilitate the trafficking in children for the purpose of adoption', Tijdschrift voor Familie- en Jeugdrecht 2019 vol. 5, p. 104-110.

106 Loibl 2019, p. 302.

107 Ibid. 
from the authorities long enough before seeking an adoption run higher chances of being allowed to keep the adoptee. Thus, ultimately, the best interests of the illegally adopted child and Article 8 ECHR offer protection to faits accompli in violation of legal rules.

The tendency of the German and Dutch courts to allow adopters to keep the child they illegally brought to Germany and the Netherlands, respectively, undermines the high standards and principles laid down in international and national law, which seek to protect not only the rights and interests of the individual children concerned but also those of children in general. ${ }^{108}$ Article 3(1) UNCRC provides that "in all actions concerning children [...] the best interests of the child shall be a primary consideration". The indefinite phrase ' $a$ primary consideration' instead of 'the primary consideration' indicates that the consideration of the child's best interests is of primary importance among other considerations but that the child's best interests do not have absolute priority overriding other interests. ${ }^{109}$ Hence, the interests of children in general as well as the interests of the state to prevent disorder and crime also have to be taken into consideration when dealing with an illegal adoption.

In German and Dutch case law on private international adoptions, the courts fail to properly balance the various interests at stake. They give priority to the interests of the children in concreto, whereas considerably less attention is being paid to the abstract but not less fundamental interests of children in abstracto that the adoption laws also aim to protect. ${ }^{110}$ In their judgments, the need to bring the illegal activities of the adopters to an end, by removing the privately adopted child and/or refusing to recognize the private adoption, and to thereby deter other prospective adopters from bypassing the national adoption laws, is hardly given attention, regardless of the reprehensibility of the adopters' illegal actions.

In Campanelli and Paradiso v. Italy, the ECtHR did no longer accept the intended parents to draw their right from an illegal factual situation which they themselves created and to refer to the best interests of the surrogate-born child as a shield from state intervention. The Court's judgment stands in the way of the current German and Dutch case law which seems to automatically recognize private intercountry adoptions. Applying the Court's considerations in Campanelli and Paradiso $v$. Italy to cases of private adoptions implies that national courts must engage in a more balanced assessment of the different rights and interests involved. Removing an illegally adopted child can in some cases be justified and even necessary if it serves to protect important public interests: on the one hand, this measure sanctions the illegal activities of the adopters. On the other, it protects the rights and interests of children in general by deterring others from pursuing an adoption that is violating national and international law. Such a measure should be considered if the adoptee has not lived with the new family long enough to establish a strong emotional bond or if the actions of the adopters were particularly objectionable

108 Ibid.

109 UN Commission on Human Rights, Report of the Working Group on a Draft Convention on the Rights of the Child, (1989) 02 March 1989, UN Doc. E/CN. 4/1989/48, para. 121.

110 S.W.E. Rutten and K.J. Saarloos, 'De erkenning van de kafala in het IPR en het vreemdelingenrecht', Tijdschrift voor Familie- en Jeugdrecht 2007 vol. 12, no. 125. 
(e.g. because they were actively involved in illegally obtaining the adoptee from his or her birth parents through purchase or abduction). If, however, separating the child from the private adopters is considered incompatible with his or her best interests and the right to respect for family life (taking into account the duration of the cohabitation, the quality of the personal ties, and the role played by the applicants vis-à-vis the child), the courts should not automatically recognize, and thereby validate after the fact, the private adoption. Rather, in order to respect the adoptee's right to know his or her origins, the courts should ensure that (with the help of the adopters) as much detailed information as possible about the illegal adoption is obtained and stored for the adoptee to access later before the situation brought about illegally is being recognized.

\section{Conclusion}

Within the past half century, a market in adoptable children has emerged. Numerous couples and individuals in Western countries who are unable to have their own children look for alternative, often illegal, means, in countries of the Global South to form a family: they adopt a child privately, without the involvement of an adoption agency, because they want to circumvent the lengthy and cumbersome adoption procedure and/or because they do not meet the strict adoption requirements; or they enter into a commercial surrogacy agreement.

Private intercountry adoptions are particularly risky, mainly because there is no opportunity for supervision and control by the authorities in the receiving countries. However, even though private adoptions violate both international and national law, the authorities in the receiving countries usually recognize them. In Germany and the Netherlands, the best interests of the children concerned and the right to respect for private and family life according to Article 8 ECHR seem to make it impossible for the family courts to end the unlawful situation created by adopters, by refusing to recognize the private adoption and by removing the child from the illegal adopters. The best interests of the illegally adopted child and Article $8 \mathrm{ECHR}$, thus, serve the private adopters as a shield from any repercussion for their actions and offer protection to faits accompli in violation of legal rules.

In the recent judgment Campanelli and Paradiso v. Italy, the ECtHR sends out a clear message to couples and individuals seeking to form a family by illegal means. The Court dealt with the question as to whether removing a child from the care of an Italian couple that entered into a surrogacy agreement with a Russian clinic, given that surrogacy is illegal in Italy, violated Article 8 ECHR. Contrary to previous case law, in which the ECtHR placed a strong emphasis on the best interests of the individual child concerned, the Court seemed to attach more weight to the need to prevent disorder and crime by putting an end to the illegal situation and discouraging other citizens from bypassing national laws. It did, thus, no longer accept parents to draw their right from an illegal factual situation which they themselves created and to refer to the best interests of the surrogate-born child as a shield from state intervention.

Considering the shifting focus of the ECtHR on the prevention of unlawful conduct, the current German and Dutch case law that seems to automatically recog- 
nize private adoptions will be difficult to hold in the future. Applying the Court's considerations in Campanelli and Paradiso v. Italy to cases of private adoptions implies that the national courts have to engage in a more balanced assessment of the rights and interests at stake. The latter do not only have to attach weight to the interests of the individual child concerned but also to the abstract but not less fundamental interests of children in general as well as the need to bring the adopters' illegal activities to an end and to deter others from bypassing the adoption laws. Furthermore, the courts should not only take into account the right to respect for family life but also the adoptee's right to know his or her origins, another aspect protected by Article 8 ECHR. 